Jesús Moran Cepedano*

ORCID: 0000-0003-1939-8656

Rocca di Papa, Włochy

\title{
Antropologiczna perspektywa Chiary Lubich na trzecie tysiąclecie
}

\section{Chiara Lubich's Anthropological Perspective for the Third Millennium}

Summary: Today, we are witnessing the wide-ranging effects of a true anthropological emergency which, at all levels, calls for a new vision of the future in order to be addressed effectively and to change from being a huge challenge to becoming a new opportunity regarding the fate of future generations. To respond adequately to this task, it is necessary on the one hand to listen to authoritative voices that can interpret our times and, on the other, to refer to some essential phases of human history that came before the present phase. In an undertaking of this kind, it is of fundamental importance to reflect on how all this research has been received and understood within the ecclesial context and what consequences it has brought to the actual self-awareness of the Church. It is in this context that the anthropological and educative approach arising from the charism of Chiara Lubich and the experience of the Focolare Movement come into play.

* Jesús Moran Cepedano, hiszpański filozof i teolog; doktor teologii na Papieskim Uniwersytecie Laterańskim; wykładowca i konsultant duszpasterstwa studentów Papieskiego Uniwersytetu Katolickiego w Chile (1987-1991); współprezydent Ruchu Focolari (od 2014). Adres: Via di Frascati, 306, 00040 Rocca di Papa RM, Italia; e-mail: jesus.moran@focolare.org. 
Keywords: second modernity; anthropological emergency; the humanism of unity.

Streszczenie: Doświadczamy dzisiaj poważnego kryzysu antropologicznego, co powoduje konieczność stworzenia nowej, perspektywicznej wizji, aby móc na niego skutecznie odpowiedzieć i aby z wielkiego wyzwania stał się okazją do wzrostu dla nowych pokoleń. Aby sprostać temu zadaniu, trzeba z jednej strony słuchać autorytatywnych głosów, które wyjaśniają nasze czasy, a z drugiej strony odnieść się do niektórych istotnych etapów historii ludzkości, które poprzedziły aktualny stan. W tym przedsięwzięciu najistotniejsza jest refleksja nad tym, jak wszystko to zostało przyjęte i zinterpretowane w Kościele i jakie konsekwencje miało dla jego samoświadomości. Właśnie $\mathrm{w}$ ten kontekst wpisuje się propozycja antropologiczno-wychowawcza, która wypływa z charyzmatu Chiary Lubich i z doświadczenia Ruchu Focolari.

Slowa kluczowe: inna nowoczesność; kryzys antropologiczny; humanizm jedności.

Zanurzeni w trzecim tysiącleciu, bardziej niż kiedyś widzimy pierwsze symptomy poważnego kryzysu antropologicznego zapowiadanego od dziesięcioleci. Dziś obejmuje on wszystkie obszary wiedzy i działania człowieka. W istocie wydaje się, że podjęcie jakiejkolwiek tematyki związanej z człowiekiem nie będzie jasne i koherentne, jeśli nie będziemy mieli odwagi pogłębienia antropologii, która leży u jej podstaw.

Niezbędne jest zatem spojrzenie perspektywiczne, bo tylko takie gwarantuje głęboki i syntetyczny wgląd. Oznacza to także ogromną możliwość i wielkie wyzwanie, od czego w dużej mierze może zależeć los przyszłych pokoleń. Jak w tę perspektywę wpisuje się antropologiczno-edukacyjna propozycja, która wyłania się z charyzmatu Chiary Lubich i z doświadczenia Ruchu Focolari?

Należy wyjść od stwierdzenia, że pedagogika opiera się zawsze na antropologii, tzn. - jak stwierdza Arystoteles - na wizji i dyskursie o człowie$\mathrm{ku}$, jako że jest to nauka, która zajmuje się człowiekiem z punktu widzenia jego różnych zachowań społecznych. Co więcej, w związku z tym, że ów dyskurs o człowieku nie jest jednoznaczny, poszczególne programy wychowawcze poddane są rozmaitym prądom myślowym w obszarze pedagogiki, co pokazuje zarówno historia wychowania, jak i praktyka pedagogiczna oraz 
refleksja nad wychowaniem. $Z$ tego też względu należy na moment zatrzymać nad współczesnym kontekstem kulturowym z jego sprzecznościami $\mathrm{i}$ ich odbiciem $\mathrm{w}$ antropologii, tak jak jest on interpretowany przez niektóre miarodajne głosy, żeby następnie przejść do krótkiego przeglądu wielkich etapów ludzkiej historii, które poprzedziły aktualną fazę i które mogą rzucić na nią światło.

Następnie trzeba będzie zastanowić się na tym, co zostało przyjęte i zinterpretowane $\mathrm{w}$ środowisku kościelnym i jakie to miałoby mieć konsekwencje dla samoświadomości Kościoła, ażeby wreszcie pokusić się o syntetyczne umiejscowienie perspektywy antropologicznej Chiary Lubich, ukazując edukacyjny wkład wypływający z praktyki życia, która od kilku dziesięcioleci jest udziałem Ruchu Focolari, pozostawiając studiom akademickim gruntowne zbadanie ich treści i metod.

\section{Bezdroża innej nowoczesności ${ }^{1}$}

Proces, którego od ponad trzech wieków jesteśmy świadkami na Zachodzie, pomijając wszystkie rozróżnienia, konflikty i sprzeczności, jest zazwyczaj określany jako proces modernizacji, który z antropologicznego punktu widzenia można odczytywać w największym skrócie jako proces indywidualizacji.

Zygmunt Baumann w swojej pracy pod wiele znaczącym tytułem $R a$ zem osobno opisuje to tymi słowami:

Indywidualizacja polega na transformacji tożsamości ludzkiej z czegoś „danego" na „,zadane”, na przypisaniu aktorom odpowiedzialności, związanej z realizacją tego zadania i konsekwencjami (efektami ubocznymi) ich działań. Innymi słowy, polega na ustanowieniu jakiejś autonomii de iure (chociaż niekonieczne autonomii de facto). Istoty ludzkie nie przychodzą na świat z już zdefiniowaną tożsamością².

W jego opinii współczesna epoka miałaby polegać na czymś w rodzaju biegu ku samookreśleniu. Wydaje się jednak, że rezultaty nie spełniają ocze-

${ }^{1}$ Ten tekst jest opracowaniem, szeroko przepracowanym i poprawionym, wystąpienia wygłoszonego na Sympozjum ,Jako w niebie tak i na ziemi”, które odbyło się na Papieskim Uniwersytecie Urbanianum w Rzymie, 20 marca 2010 r.

2 Zygmunt Bauman, Individualmente insieme (Reggio Emilia: Diabasis, 2008), 31. 
kiwań. Autor stwierdza: „zdolność kobiet i mężczyzn zindywidualizowanych do autoafirmacji z reguły nie osiąga tego, co jest wymagane od efektywnego samostanowienia"3. I moglibyśmy dodać, że nie prowadzi w żadnym wypadku do tworzenia społeczeństwa bardziej godnego człowieka i takiego, w którym wszystkim lepiej się żyje, a tym bardziej do solidarnego współistnienia między równymi. Wręcz przeciwnie, wydaje się, że ten proces prowadzi generalnie do pewnego rodzaju „dezintegracji obywatelskiej”4 ze zgubnymi skutkami dla samych jednostek. Istotnie, zauważamy:

„wspólnoty” kruche i krótkotrwałe, a także emocje rozproszone i pogubione, które w błędny sposób przechodzą od jednego do drugiego celu i krążą w płonnym poszukiwaniu pewnej przystani: wspólnoty opartej o wspólne zmartwienia, na wspólnych lękach i nienawiści, jednym słowem są to wspólnoty czaso$\mathrm{we}^{5}$.

Odnosząc się do Urlicha Becka, podkreśla, że z takiego rozpadu wynika:

Nagie, agresywne, przerażone Ja, w desperackim poszukiwaniu pomocy i miłości. W owym poszukiwaniu siebie i solidarnej społeczności łatwo gubi się w swojej wewnętrznej dżungli. [...] Istota na zakręcie we mgle swojego Ja jest już niezdolna do uświadomienia sobie, że ta izolacja, to „pełne osamotnienia uwięzienie Ja" jest przekleństwem mas ${ }^{6}$.

I podsumowuje:

Ta ogromna przepaść między prawem do samostanowienia a zdolnością do kontrolowania kontekstów społecznych, które takie samostanowienie czynią możliwym albo nierealnym, wydaje się główną sprzecznością ,innej nowoczesności”, epoki, w której przez próby i błędy, krytyczne refleksje i odważne eksperymenty będziemy musieli nauczyć się je wspólnie rozwiązywać7.

3 Tamże, 35.

${ }_{4}$ Tamże, 37.

5 Tamże, 38.

6 Tamże, 39.

7 Tamże. Inni autorzy mówią o neoindywidualizmie, odnosząc się do kontekstu, w którym żyją mężczyźni i kobiety naszych czasów. Ten neoindywidualizm miałby być paradoksalnym skutkiem społeczeństwa coraz bardziej globalnego, a więc i poddanego hiper-relacyjności. Główne jego elementy to: dezintegracja i brak spójności społecznej; powstawanie nowej klasy 
Baumanowi, który jest rzecznikiem idei „radykalizacji nowoczesności”» jako drogi wyjścia, odpowiada Jeremy Rifkin, który kilka lat później w swojej książce Empatyczna cywilizacja proponuje spojrzenie na cywilizację z punktu widzenia tej wartości i próbuje zgłębić takie cechy ludzkie, jakie mogłyby pomóc wyjść z obecnego kryzysu.

Coraz bardziej skomplikowane i wygłodniałe cywilizacje - stwierdza - pozwalają człowiekowi ścieśniać przestrzeń i czas, rozszerzać [...] w jakiś rodzaj centralnego, kolektywnego systemu nerwowego, aby objąć coraz szersze obszary egzystencji. Robimy to wszystko, aby odzyskać znaczenie poprzez przynależność do bogatszego i głębszego środowiska rzeczywistości ${ }^{9}$.

\section{I przestrzega:}

Pojawia się i radykalnie nabiera mocy nowa idea ludzkiej natury, która ma rewolucyjne implikacje w sposobach interpretowania i organizowania naszych relacji społecznych i środowiskowych w przyszłości. Odkryliśmy Homo empaticus $^{10}$.

Jeszcze jednym dowodem na to, jak naglącą jest ta kwestia, jest jej widoczny wpływ na edukację, która według Marthy Nussbaum przechodzi globalny kryzys na taką skalę, jak nigdy dotąd:

Mam na myśli kryzys, który pozostaje niezauważony, niczym potwór; kryzys, który na dłuższą metę najpewniej będzie miał dla demokratycznej samorządno-

pariasów cywilizacji globalnej; przeobrażenie zdolności do konsumpcji w podstawowe kryterium włączenia lub wykluczenia społecznego; prywatyzacja więzi społecznych; nierówność jako faktor determinujący wykluczenie społeczne; kryzys etyki prywatnego bogacenia się ponad wszystko; pojawienie się indywidualizmu pozbawionego świadomości, że wypływa z destrukcyjnego nihilizmu i paradoks wyrzeczenia i nieposiadania; destrukcja wspólnotowego, solidarnego i demokratycznego wymiaru relacji społecznych; tryumf tego, co prywatne, nad tym, co wspólne; kształowanie się pewnego rodzaju autyzmu społecznego między ludźmi; tendencja do radykalizacji kulturowej, etnicznej, wspólnotowej, miejskiej, religijnej czy generalnie tożsamościowej grup społecznie wrażliwych, a w związku z tym łatwiej podatnych na manipulację [por. Maria José Fariñas Dulce, „Neoindividualismo y desigualdad”, El País, 5.01.2005, https:// elpais.com/diario/2005/01/05/opinion/1104879608_850215.html, 20.09.2018].

8 Por. Bauman, Individualmente, 39.

9 Jeremy Rifkin, La civiltà dell'empatia (Milano: Mondadori, 2010), 39.

10 Tamże, 42. 
ści o wiele gorsze skutki. To światowy kryzys edukacji. W programach nauczania, które społeczeństwa serwują młodym, wprowadzane są radykalne zmiany, które nie zostały poważnie przemyślane. W pogoni za zyskiem poszczególne państwa i ich systemy nauczania, nie zważając na nic, rugują umiejętności niezbędne dla podtrzymywania przy życiu demokracji ${ }^{11}$.

Wyraźnie krytyczna analiza panoramy światowej, jaką Nussbaum ukazuje w swoim tekście, prowadzi do wniosku nawiązującego do Rabindranatha Tagorego, który zwracając uwagę na szaleńczy pęd do posiadania dóbr materialnych, stwierdza, że tak właśnie rozpoczyna się ,,proces stopniowego samobójstwa, wynikający z kurczenia się duszy”12. I jakkolwiek dziwne albo zaskakujące może wydawać się odwołanie do pojęcia czysto religijnego, amerykańska filozof doprecyzowuje, w jakim sensie termin ten może być przez wszystkich zrozumiały i przyjęty. Oznacza to:

zdolność myślenia i pobudzenia wyobraźni, która czyni z nas ludzi, a naszym relacjom z innymi dodaje głębi, zamiast sprowadzać je do relacji opartych na wzajemnym wykorzystywaniu i manipulacji. [...] zdolność do krytycznego myślenia i wykroczenia poza więzy lokalne i spojrzenia na globalne problemy z perspektywy „obywatela świata”, wreszcie zdolność do współczucia i zrozumienia trudnej sytuacji drugiej osoby ${ }^{13}$.

W istocie chodzi o to, by brać pod uwagę fakt, iż każda relacja zachodzi zawsze $w$ ramach przestrzeni antropologicznej i wymaga koniecznego szacunku i nieodzownej troski. Jak nie wspomnieć tu księdza Lorenza Milaniego i napisu, który zawiesił na ścianie swojej szkoły w Barbianie koło Florencji: „Zależy mi” (I care).

Kończąc ten krótki przegląd dotyczący kontekstu, w którym współcześnie jesteśmy i z którym musimy się zmierzyć zwłaszcza na polu edukacji, warto przytoczyć znaczące, mogące być światłem w tunelu, słowa Georga Steinera na temat zadania nauczycieli:

rośnie we mnie niepewność co do zasadności, a także podstawowych prawd owej ,„profesji”. Biorę ten termin w cudzysłów, aby podkreślić jego zawiłe ko-

${ }^{11}$ Martha C. Nussbaum, Nie dla zysku. Dlaczego demokracja potrzebuje humanistów (Warszawa: Kultura Liberalna, 2016), 17-18.

12 Tamże, 17.

13 Tamże, 22-23. 
rzenie sięgające religijnych i ideologicznych antecedensów. Profesja „profesora" - sam już ten zwrot nie jest najzgrabniejszy - obejmuje wszelkie możliwe niuanse, od rutyny przez życie wyzbyte iluzji aż po wzniosłe poczucie powołania ${ }^{14}$.

\section{Fundamentalne etapy rozwoju antropologii na Zachodzie}

Skoro zasadnicza lektura tego etapu ludzkości wydaje się w istocie pewna - pomijając zrozumiałe różnice związane $\mathrm{z}$ różnymi środowiskami kulturowymi - to tym, co napotyka na trudności interpretacyjne, jest prowadzenie dogłębnej analizy etiologicznej fenomenów, a zwłaszcza poszukiwanie możliwych dróg rozwiązania, które są opracowywane, a przecież niepozbawione ryzyka popełnienia różnego rodzaju błędów. Żeby zrobić krok naprzód, trzeba rozpatrzyć w szerszym kontekście tę inną nowoczesność z jej fenomenami indywidualizacji i pojawiający się w niej - jeśli przyjmujemy tezę Rifkina - nowy typ człowieka, w procesie rozwoju samoświadomości ludzkości, w którym wśród wielu etapów z pewnością można dostrzec te zasadnicze. Sugestywną i syntetyczną charakterystykę tego procesu - odnoszącą się szczególnie do Zachodu - odnajdujemy w pismach Giuseppego M. Zanghíego ${ }^{15}$, który przez dziesięciolecia zajmował się tym problemem. Jego zdaniem zasadniczo różne koncepcje człowieka, jakie do tej pory zostały wypracowane na Zachodzie, można sprowadzić do dwóch wielkich wizji antropologicznych, związanych z odpowiadającymi im sposobami rozumienia i życia w relacji do Absolutu, a co za tym idzie, odpowiadającym im sposobem myślenia i działania. Niemożliwe jest oczywiście oddzielenie tych koncepcji, bo nie są to środowiska zamknięte, dokładnie zdefiniowane, określone w czasie i przestrzeni. Jednak tylko wielkie idee historyczne (jest to bardziej zagadnienie filozofii historii aniżeli samej historii) funkcjonują obok siebie autonomicznie, mimo że przenikają się nawzajem w późniejszych etapach.

${ }^{14}$ George Steiner, Nauki mistrzów (Poznań: Zysk i S-ka, 2007), 9.

15 Por. Giuseppe Maria Zanghí, „Il pensare come amore. Verso un nuovo paradigma culturale", Nuova Umanità 145 (2003): 1-19; Giuseppe Maria Zanghí, Notte della cultura europea (Roma: Città Nuova, 2007); Giuseppe Maria Zanghí, Leggendo un carisma. Chiara Lubich e la cultura (Roma: Città Nuova, 2015). 
Pierwsza faza charakteryzuje się „myśleniem kategoriami mitu”"16, co jest typowe dla pierwszego, długiego stadium rozwoju ludzkości. W kulturze mitologicznej, we wszystkich tradycjach kulturowych, podmiotem myślącym jest grupa, a przedmiotem myślenia jest bóstwo. Obydwie te rzeczywistości - myślący i przedmiot myśli - są nieustannie zanurzone w świetle tego ostatniego. Fundamentalną kategorią myślenia jest zatem pamięć reprodukująca początkową rzeczywistość, w której chce się zawsze pozostawać. Najważniejsze jest Dobro i pojawia się figura Wielkiej Matki, która strzeże i karmi. Podstawowe elementy tej teoretycznej koncepcji i doświadczenia egzystencjalnego to:

- zanurzenie w bóstwo, pojmowane jako łono, od którego człowiek się nie odróżnia;

- głęboka komunia z uniwersum;

- poczucie całkowitej zależności od uniwersum;

- sakralizacja i rytualizacja egzystencji;

- dominująca rola klasy kapłańskiej;

- rozpowszechnione przekonanie o tajemniczym rozdarciu Jedności, kiedy trzeba brać pod uwagę osobliwość.

Drugi etap to ten, który pojawia się wraz z przejściem do „myślenia w kategoriach logosu"17. Około VI w. przed Chr. zaczyna się to, co Karl Jaspers nazwał epoką osiową, w której ukazują się - prawie jednocześnie w zaskakujący sposób - fenomeny podobne we wszystkich tradycjach kulturowych: profetyzm w Izraelu, Budda, Upanishad w Indiach, Konfucjusz i Lao Che w Chinach, Zaratustra w Persji i presokratejczycy w Grecji. Są tu widoczne charakterystyczne cechy, odmienne do tych z poprzedniej fazy:

- człowieka stawia się wobec bóstwa, rozumianego jako odmienne od niego;

- zaczyna się proces uniezależnienia i autonomii;

- pojawia się logos jako sposób myślenia o bóstwie;

- myślenie staje się ćwiczeniem dyskursywnym, a nie tylko kontemplacyjnym czy zanurzeniem się w bóstwo;

- pojawiają się osoby mędrców i myślicieli;

- zaczyna zanikać sens pierwotnego upadku i potrzeby zbawienia.

W kulturze logos podmiotem myślącym nie jest już grupa, lecz ,pojedynczy człowiek". Chodzi o pojmowanie całości, ale wychodząc od jednost-

16 Por. Giuseppe M. Zanghí, „Il pensare”, 2-6.

17 Tamże, 6-11. 
ki, a zatem od logosu, który podmiot pojmuje. Przedmiot myślenia będzie wieloraki i różny, a rzeczywistość zmienna. Myślący i przedmiot myśli będą coraz bardziej zagłębiać się w świecie rozumu. I to będzie właśnie ta kultura, która po prawie dwóch tysiącach lat, przynajmniej na Zachodzie, dotrwa do modernizmu, który zradykalizuje supremację rozumu aż po heglowski idealizm, po którym przyjdzie reakcja irracjonalności, potem nihilizm, a wreszcie postmodernizm.

Można także powiedzieć, posługując się innymi rodzajami hermeneutyki - zachowując jednak należytą ostrożność, by uniknąć niebezpieczeństwa zbytniego uproszczenia - że pierwszy etap definiuje wymiar czysto kosmo-teocentryczny, typowy dla rozwoju świadomości ludzkości w świecie antycznym, podczas gdy drugi kieruje się ku wymiarowi logo-antropocentrycznemu, aż do naszych czasów charakteryzującemu nowoczesność z jej wszystkimi osiągnięciami, które przed kilkoma dziesięcioleciami ustąpiły miejsca obrazowi zupełnie niesłychanemu.

Jest to właśnie umiejscowiony w horyzoncie innej nowoczesności obraz, o którym wspomnieliśmy wcześniej, przede wszystkim w interpretacji Baumana i Rifkina. Proces indywidualizacji podkreślony przez Baumana i pojawienie się tego, co Rifkin nazywa homo empaticus, sytuują się na skrzyżowaniu historii, u progu trzeciego tysiąclecia, i zdają się wskazywać, że - mimo niezliczonych trudności i możliwych niebezpiecznych regresów ludzkość kroczy ku trzeciemu etapowi, który zwraca się w stronę tego, co moglibyśmy zdefiniować jako wymiar personalistyczny.

W tym momencie pojawia się zasadnicza kwestia, ponieważ - jeśli chcemy uchwycić prawdziwe znaczenie tego, co się dzieje - nie możemy pominąć problemu typowo metafizycznego, od którego zależy każde możliwe rozważanie na temat natury współżycia ludzi. Jak podkreślił Xavier Zubiri: „prawdziwy problem społeczności polega na tym, że mówi się nam, na ile i w jakiej formie inni tworzą część mojej rzeczywistości, i wzajemnie, na ile ja tworzę rzeczywistość innych" ${ }^{18}$. Stoimy zatem przed kwestią fundamentalną.

${ }^{18}$ Xavier Zubiri, Tres dimensiones del ser humano: individual, social, histórica, red. Jordi Corominas (Madrid: Alianza Editorial - Fundación Xavier Zubiri, 2006), 51. W istocie dla hiszpańskiego myśliciela: „ludzie są w istotny sposób współ-realni i zasadniczo nie znaczy, że tacy są, bo nie mogą inaczej, ale to, że każdy jest, jest wpół-realny z innymi z powodu swojej własnej realności. Współżycie ludzi to specyficzny charakter własnej realności w istocie ludzkiej jako takiej" [tamże]. 


\section{Kilka wyzwań, przed którymi staje chrześcijaństwo i Kościól}

Jaka była recepcja i interpretacja tego wszystkiego wewnątrz kontekstu kościelnego i jakie konsekwencje przyniosło to dla samoświadomości Kościoła i jego działania?

Trzeba wyjść od stwierdzenia, że chrześcijaństwo powstało właśnie podczas pełnego rozkwitu fazy kulturowej logos, z objawieniem odwiecznego Słowa, które się wciela, aby wskazać drogę ku prawdziwemu przebóstwieniu, rozumianemu według Zanghíego powszechnie tylko jako mit, do którego sama kultura nigdy nie dotarła z powodu nieuniknionego skupienia się na samym rozumie albo z powodu swojej niezdolności do przekroczenia rzeczywistości wielości Jedności i rozróżnienia w jedności.

Znajdujemy się w centrum refleksji, jaką - mimo różnych i często przeciwstawnych form - Zachód i Wschód wypracowały przez prawie dwa tysiąclecia i która prowadzi do kluczowego problemu: do owego nieuniknionego współistnienia rzeczywistości Bytu i Niebytu, które Zanghí syntetycznie wyjaśnia z rzadką i precyzyjną błyskotliwością:

ludzkość przeszła tę drogę, którą rozpoczęła na etapie mitu i na której dojrzewała na etapie racjonalności, dodając od siebie ,grzech”. Owo tajemnicze „NIE”, przeczuwane już przez mity jako coś zawartego w boskości (a które Logos wcielony objawi jako sam Byt Boga, Trójcę, Miłość-otwartą-w-Darze) stało się doświadczeniem ludzkości „kuszonej” jako „nie” negatywne, jako odrzucenie. Tak jakby ludzkość sama z siebie nie była zdolna podtrzymać mocy Miłości, którą jest Bóg Trójjedyny w ogniu jedności-odróżnienia. Oczekiwała na odwieczny Logos w stworzonym ciele Słowa Wcielonego ${ }^{19}$.

I tylko w tym horyzoncie można poprawnie umiejscowić proces przejścia od indywiduum do osoby, co nie jest takie oczywiste i nie może nie brać pod uwagę chrześcijaństwa. Podobnie chrześcijaństwo w trzecim tysiącleciu nie może nie brać pod uwagę innej nowoczesności, co stwierdził z mocą i zaskakującą dalekowzrocznością Jan Paweł II już w 1982 r. podczas V Sympozjum Biskupów Europy:

19 Zanghí, „Il pensare”, 10. 
Być może zaskoczeni, odkrywamy, że kryzysy i pokusy Europejczyka i Europy są kryzysami i pokusami chrześcijaństwa i Kościoła w Europie. [...] W tym świetle chrześcijaństwo może odkryć w przygodzie europejskiego ducha pokusy, niewierności i zagrożenia, które są właściwe człowiekowi w jego istotnej relacji do Boga w Chrystusie ${ }^{20}$.

W tych proroczych słowach - wypowiedzianych w czasach równie niepewnych - odnajdujemy klucz do odczytania tego, co stało się w ostatnich dziesięcioleciach i co popchnęło Kościół - „mający wielkie doświadczenie w sprawach ludzkich"21 i zakorzeniony w mądrości Ewangelii - do postawienia sobie pytań dotyczących jego kompetencji związanych z procesami humanizacji, ujętymi w strzeżonym przez niego przesłaniu, po to, by umieć towarzyszyć doświadczeniom mężczyzn i kobiet w skomplikowanej sytuacji historycznej. Nie mogło być inaczej, ponieważ z powodu dramatycznych procesów historycznych także Kościół został poddany próbie poprzez swoich członków i jest zmuszony dostrzegać swoje cienie i blaski, osiągnięcia i porażki, swoje upadki i nadzieje. Prawdziwym wyzwaniem jest dla niego przede wszystkim zauważalny kryzys antropologiczny, który praktycznie obejmuje wszystkie obszary działania i ludzkiego istnienia. Nie bez powodu pontyfikat Jana Pawła II rozpoczął się od programowej encykliki Redemptor hominis, w której papież z mocą potwierdził fakt, że człowiek jest i zawsze będzie drogą Kościoła. W encyklice odwoływał się do punktu 22 Konstytucji duszpasterskiej o Kościele w świecie współczesnym Gaudium et spes:

Adam bowiem, pierwszy człowiek, był typem Tego, który miał przyjść, to znaczy Chrystusa Pana. Chrystus, nowy Adam, właśnie w objawieniu tajemnicy Ojca i Jego miłości objawia w pełni człowieka samemu człowiekowi i odsłania przed nim Jego najwyższe powołanie ${ }^{22}$.

Tajemnica człowieka ukazała się w tajemnicy człowieka-Boga, który ją objawia $^{23}$. Pontyfikat ten zakończył się właściwie wielkim jubileuszem roku

${ }^{20}$ Giovanni Paolo II, „V Simposio dei Vescovi d'Europa”, L'Osservatore Romano, 7 ottobre 1982.

${ }^{21}$ Paweł VI, Populorum progressio, nr 13, AAS 59 (1967): 257-299; Wiadomości Diecezjalne (Katowice) 36 (1968): 205-225.

${ }^{22}$ Sobór Watykański II, „Konstytucja duszpasterska o Kościele w świecie współczesnym Gaudium et spes", nr 22, w: Sobór Watykański II. Konstytucje. Dekrety. Deklaracje (Poznań: Pallottinum, 1967).

${ }^{23}$ Por. tamże. 
dwutysięcznego i Listem apostolskim Novo Millennio Ineunte, w którym moglibyśmy powiedzieć - z perspektywy wewnątrzkościelnej Jan Paweł II wzywał Kościół do podjęcia wyzwania profetycznego, bo jedynie dzięki niemu może stać się on zaczynem i solą społeczeństwa trzeciego tysiąclecia. A czynił to, wskazując na krok nieuchronny i konieczny do tego, co nazywa „eklezjologią komunii”"24.

Przyjmowana jako pewnego rodzaju doktryna Soboru Watykańskiego II samoświadomość Kościoła powinna teraz stać się konkretną praktyką i ukazać się chrześcijanom. By uczynić ją bardziej owocną, Jan Paweł II śmiało proponuje tworzenie „szkół eklezjologii komunii” ${ }^{25}$, w których można by nauczyć się i praktykować życie wspólnotowe w jego prawdziwym wymiarze.

W tym samym duchu Benedykt XVI - jak mało kto świadomy klimatu kulturowego pierwszych lat trzeciego tysiąclecia - zaczyna prowadzić Kościól, zdecydowanie kierując uwagę na absolutne novum chrześcijaństwa: Deus caritas est, ukazując w ten sposób prawdziwe oblicze Boga i jego bycie „wobec” stworzeń i „w” nich. Miłość, która staje się nadzieją dla człowieka (spe salvi), tzn. zadatkiem ziemskiej sprawiedliwości i wiecznej chwały. Miłość utożsamia się z prawdą ${ }^{26}$, do niej dąży, bo od niej pochodzi. Szczególnie w Caritas in Veritate to antropologiczne podkreślenie jest najbardziej rozwinięte. W n. 75 jest wyraźnie powiedziane: „trzeba dzisiaj stwierdzić, że kwestia społeczna stała się radykalnie kwestią antropologiczną"27. Skoro świat cierpi z powodu braku myślenia, jak stwierdza Benedykt XVI, podejmując motto Pawła VI z Populorum progressio, to ta pustka może być zapełniona tylko poprzez ,nową syntezę humanistyczną"28, która za sprawą realnej odnowy przezwycięży spłycenie współczesnej kultury. Chodzi o to, by skupić się na rozwoju moralnym, który wymaga także wysiłku inteligencji i miłości, połączonych w nowej syntezie, aby ,doprowadzić do wzajemnego oddziaływania różnych poziomów ludzkiej wiedzy” 29 w ,uporządkowanej interdyscyplinarności” ${ }^{30}$. Potrzebne jest pilne „rozszerzenie naszej koncepcji

${ }^{24}$ Jan Paweł II, Novo Millennio Ineunte, nr 43 (Wrocław: Wydawnictwo TUM, 2000).

25 Jan Paweł II na Synodzie Rzymskim - cytowane w: Piero Coda, „I movimenti ecclesiali, dono dello Spirito”, w: Pontificium Consilium pro Laicis, I movimenti nella Chiesa (Città del Vaticano: Libreria Editrice Vaticana, 1999), 96.

${ }^{26}$ Benedykt XVI, Caritas in Veritate (Poznań: Księgarnia św. Wojciecha, 2006).

27 Tamże, nr 75.

${ }^{28}$ Por. tamże, nr 21.

29 Tamże, nr 30.

${ }^{30}$ Por. tamże. 
rozumu" ${ }^{\prime 2}$, aby był on zdolny przyjąć prawdziwą rzeczywistość człowieka i wyzwania, jakie otwierają nowe procesy światowe ${ }^{32}$.

Z pełnym mądrości spojrzeniem na cały proces Benedykt XVI utrzymuje, że:

Przejście wpisane w proces globalizacji przedstawia wielkie trudności i niebezpieczeństwa, które można przezwyciężyć jedynie, jeśli uświadomimy sobie tę antropologiczną i etyczną duszę, która z głębi kieruje globalizację w stronę solidarnej humanizacji. [...] Pozwoli to przeżywać i nadać kierunek ludzkości w duchu relacyjności, komunii i wzajemnego dzielenia się ${ }^{33}$.

W taką światową panoramę - naznaczoną także kryzysem ekonomicznym z 2008 r. - dokładnie wpisuje się pontyfikat papieża Franciszka, umiejscowiony w czasach szczególnego zaostrzenia i pogłębienia kryzysu antropologicznego. Już w pierwszej encyklice Lumen fidei podkreśla on wyjątkową relację między prawdą a miłością, polegającą na wzajemnym przenikaniu się:

Kto kocha, rozumie, że miłość jest doświadczeniem prawdy, że to ona otwiera nasze oczy, byśmy mogli zobaczyć całą rzeczywistość w nowy sposób, w jedności z kochaną osobą. [...] Chodzi o relacyjny sposób patrzenia na świat, które staje się poznaniem dzielonym z inną osobą, patrzeniem w perspektywie drugiego człowieka i wspólnym patrzeniu na wszystko ${ }^{34}$.

Następnie w adhortacji apostolskiej Evangelii gaudium - swoistym manifeście tego pontyfikatu, co dostrzegamy z biegiem lat - uwzględniając wcześniejszą i bogatą tradycję nauczania, spośród wielu innych zagadnień papież podkreśla zwłaszcza konieczność budowania „nowych relacji zrodzonych przez Chrystusa” i na „mistyce życia razem”:

Dzisiaj, gdy sieci i narzędzia komunikacji ludzkiej osiągnęły niesłychany rozwój, stajemy przed wyzwaniem, by odkryć i przekazać „mistykę” życia razem, wymieszania się, spotkania, wzięcia za rękę, wzajemnego oparcia, uczestnic-

\footnotetext{
31 Tamże, nr 31.

32 Por. tamże, nr 33.

33 Tamże, $\mathrm{nr} 42$.

${ }^{34}$ Franciszek, Lumen Fidei, nr 27 (Watykan: Libreria Editrice Vaticana, 2013).
} 
twa w tej nieco chaotycznej masie, która może zamienić się w prawdziwe doświadczenie braterstwa, w solidną karawanę, w święte pielgrzymowanie ${ }^{35}$.

W dziełach Petera Hünermanna i Piera Cody, wydanych w ramach serii Teologia Papieża Franciszka, zostało podkreślone, że z jednej strony ojciec święty wychodzi wyraźnie od istoty nowoczesnej antropologii filozoficznej i swojej podstawowej determinacji, żeby ,być-w-świecie człowieka”" ${ }^{36}$, z drugiej zaś jego teologia: ,jest zarazem kościelna i egzystencjalna, duchowa i kerygmatyczna, mistyczna i jednocześnie społeczna. Oryginalna i bardzo osobista synteza, która ukazuje siłę przyciągania i zwięzłość. Co pokazują radość i skuteczność, którą promieniuje"37.

To podejście charakterystyczne dla jego doświadczenia i kontekstu kulturowego, z którego pochodzi, przenika cały jego horyzont antropologiczny, wyraźnie naznaczony wymiarem duszpasterskim, zauważalnym w tym wszystkim, co mówi i co robi. Niemniej, aby to uchwycić w sposób całościowy, trzeba odnieść się do określonej idei dotyczącej natury rzeczywistości stworzonej, co ukazuje syntetycznie passus z Laudato si': „cała rzeczywistość zawiera znamię Trójcy Świętej"38.

Wreszcie, w ostatniej Konstytucji apostolskiej Veritatis gaudium, dotyczącej uniwersytetów i wydziałów kościelnych, to wszystko jest ukazane również w perspektywie kulturowej i pedagogicznej. Mówi on o konieczności ,rewolucji kulturowej" 39 w znaczeniu poszerzenia rozumu ${ }^{40}$, w której uniwersytety i wydziały kościelne są wezwane do grania pierwszych skrzypiec. I wskazuje - jako odpowiedź na kryzys antropologiczny i społeczno-ekologiczny - konieczność ,zmiany modelu rozwoju globalnego” i ,redefinicji postępu" ${ }^{41}$ według czterech podstawowych kryteriów: a) „kontemplacja i wprowadzenie duchowe, intelektualne i egzystencjalne w serce kerygmatu";

35 Franciszek, Evangelii gaudium, nr 87 (Watykan: Libreria Editrice Vaticana, 2013).

${ }^{36}$ Por. Peter Hünermann, Uomini secondo Cristo oggi. L'antropologia di papa Francesco (Città del Vaticano: Libreria Editrice Vaticana, 2017), 40.

${ }^{37}$ Piero Coda, La Chiesa è il Vangelo. Alle sorgenti della teologia di papa Francesco (Città del Vaticano: Libreria Editrice Vaticana, 2017), 11.

${ }^{38}$ Franciszek, Laudato si', nr 239 (Watykan: Libreria Editrice Vaticana, 2015).

39 Por. Franciszek, Veritatis gaudium, nr 3 (Città del Vaticano: Libreria Editrice Vaticana, 2018).

40 Por. tamże, nr 3.

${ }^{41}$ Tamże. 
b) „dialog w całej jego pełni”; c) ,,inter- i trans-dyscyplinarność”; d) „potrzeba tworzenia sieci pomiędzy różnymi instytucjami”"42.

\section{Humanizm na trzecie tysiąclecie}

W zarysowanym dość ogólnie obrazie pojawia się zasadnicza kwestia, by nie pozostać tylko na poziomie dobrych postanowień: dotyczy ona rzetelnego i wyraźnego sformułowania tego, czym jest relacja interpersonalna oraz w jaki sposób powinno się ją tworzyć i redefiniować w ramach każdej wspólnoty. Jest to też pilna kwestia na płaszczyźnie wychowawczej i pedagogicznej, o czym świadczą alarmujące sygnały ze świata młodych. Jeśli tę potrzebę widać na wszystkich płaszczyznach, to w całym środowisku kościelnym wzbudziła ona wiele reakcji przejawiających się w nauczaniu ostatnich papieży, którzy uczynili z niej absolutny priorytet. Jednocześnie rozpoznając „znaki czasu”43, należy zwrócić uwagę na działanie Ducha Świętego wyrażające się w uznaniu przez Kościół charyzmatów typowych dla naszych czasów, dzięki czemu mogły one zostać urzeczywistnione w naszej historii.

Dary te, pochodzące z Niebios, oprócz tego, że proponują rozwiązania wielkich problemów ludzkości w danym czasie, są w dynamicznej relacji z Magisterium i z życiem całego Kościoła, w synergii nie tylko afektywnej czy strategicznej, lecz także teologicznej, jako że ukazują współistnienie darów charyzmatycznych i darów ministerialnych w życiu Kościoła ${ }^{44}$. To w tym kluczu interpretacyjnym możemy zrozumieć charyzmat jedności, podarowany przez Boga Kościołowi i ludzkości właśnie na przełomie tysiącleci za pośrednictwem Chiary Lubich. Charyzmat, który dzięki swemu wewnętrznemu dynamizmowi wydaje się przedstawiać prawdziwie nową propozycję antropologiczną, odpowiadającą wymaganiom i wyzwaniom naszych czasów.

Zgodnie ze znanym twierdzeniem Hansa Ursa von Balthasara, że każdy wielki charyzmat stanowi całościowe spojrzenie na rzeczywistość, wychodząc $\mathrm{z}$ istoty Objawienia ${ }^{45}$, w sposób uprawniony można dostrzec $\mathrm{w}$ charyzmacie Chiary Lubich także inną, dostosowaną do naszej rzeczywistości, wersję tego chrześcijańskiego humanizmu, który w każdych czasach cha-

\footnotetext{
42 Tamże, $\mathrm{nr} 4$.

43 Sobór, „Konstytucja”, nr 4.

${ }^{44}$ Kongregacja Nauki Wiary, Iuvenescit Ecclesia, nr 10 i 13.

${ }^{45}$ Por. Hans Urs von Balthasar, Teologica, vol. III (Milano: Jaca Book, 1992), 22.
} 
rakteryzował wielką Tradycję samego Kościoła: jest to humanizm jedności. Zawiera on także pewne wskazania dotyczące obszaru pedagogiki i wychowania ${ }^{46}$. Oczywiście, nie jest to celem tego artykułu (także dlatego, że już od kilku lat jest to przedmiotem badań naukowych, które będą punktem odniesienia), aby uwypuklić specyficzne znaczenie pedagogiczne charyzmatu i jego konkretyzacji w praktyce życia Ruchu Focolari i wszystkich społeczności, które się nim inspirują. Muszą one wyjść od prześledzenia wydarzeń historycznych, naznaczonych wymiarem typowo pedagogicznym, skoro Chiara Lubich we wczesnej młodości była przez kilka lat nauczycielką.

W tym artykule zamierza się jedynie przedstawić tę perspektywę i jej znaczenie we współczesnym kontekście kulturowym i kościelnym, sugerując kilka ścieżek refleksji, aby potem sięgnąć do całego bogactwa teoretycznego i praktycznego, które mogłoby z nich wypływać. W tym znaczeniu należałoby zasadniczo wyjść od procesu edukacji Chiary Lubich w dzieciństwie i wieku dorastania (Trydent, 1920-1936), poprzez jej formację kulturową i chrześcijańską, biorąc pod uwagę przygotowanie do zawodu nauczyciela (Trydent, druga połowa lat 30 . ubiegłego wieku) oraz okres, kiedy Lubich jest nauczycielką szkoły podstawowej, mistrzynią aspirantek Akcji Katolickiej, w końcu mistrzynią tzw. trzeciego zakonu franciszkańskiego $(1938-1943)^{47}$.

Zdecydowanie można mówić, że wraz z wielką przemianą, jaka w niej zaszła w kontekście II wojny światowej i pojawieniem się osób, które zaczęły podzielać jej styl życia i jej nauczanie, a zatem wraz z powstaniem Ruchu Focolari, rozpoczyna się ludzka i duchowa droga, która z czasem będzie obrastać w intuicje, doświadczenia, realizacje i która ukaże m.in. to, co zdaje się konstytuować prawdziwy i właściwy projekt edukacyjny, inkulturowany w najróżniejszych kontekstach geograficznych, społecznych i religijnych. Ponieważ jednak, jak to zostało już wspomniane, każda propozycja pedagogiczna opiera się na jakiejś antropologii, konieczne wydaje się uchwycenie

${ }^{46}$ Chiara Lubich, Educazione come vita, red. A. Vincenzo Zani (Brescia: La Scuola, 2010), 42-48; por. Francesco Chatel, „Alla scuola di chi?”, Nuova Umanità 6/180 (2008): 613-621; Pino Quartana, „Introduzione. Avere il Maestro tra di noi”, w: Chiara Lubich, Una famiglia per rinnovare la società (Roma: Città Nuova, 1993), 105-108; Donato Falmi, „Presentazione della collana Studi e Documenti”, w: Qui c'è il dito di Dio. Carlo de Ferrari e Chiara Lubich: il discernimento di un carisma, red. Lucia Abignente (Roma: Centro Chiara Lubich - Città Nuova, 2017), 5-8.

${ }^{47}$ Por. Nino Carella, Silvia prima di Chiara. La ricerca di una strada nuova (Roma: Città Nuova, 2014). 
i przestudiowanie głównych cech tej antropologii, która nie może nie być chrześcijańska w najpełniejszym i najbardziej otwartym sensie, nie przyjmując przymiotnika „,chrześcijański” jako coś alternatywnego, oddzielającego, czy jeszcze gorzej: elitarnego i wykluczającego w stosunku do środowiska edukacji, ale stając się perspektywą, która umiejscawia się wewnątrz niego i w dialogu z nim. Chodzi przede wszystkim o to, aby ukazać znaczenie kulturowe charyzmatu Chiary Lubich i nie ograniczać go wyłącznie do duchowości, chociaż jest to jego pierwszorzędny i ważny aspekt. W takiej perspektywie kimś, kto osobiście i przez całe swoje życie starał się o to nieustannie i kompetentnie - poza tym, że uczestniczył w tym osobiście, będąc jednym z pierwszych towarzyszy Chiary Lubich - był Giuseppe M. Zanghí, którego już cytowaliśmy wcześniej w krótkim spojrzeniu historycznym na temat przemian kultury zachodniej. I to do niego sięgamy, aby uchwycić to, co uważał za prawdziwą nowość charyzmatu i osoby Chiary Lubich. Według niego definitywnie nihilistyczny charakter większej części współczesnej kultury jest związany $\mathrm{z}$ niekompletnym i w pewnym sensie ułomnym pojmowaniem chrześcijaństwa, w sposób szczególny „skandalu krzyża”, z tajemniczym i niepokojącym krzykiem Jezusa przed śmiercią, dającym wyraz poczuciu opuszczenia (por. Mt 27,46; Mk 15,34; Ps 22,2).

Dla Zanghíego jedyna możliwość zmartwychwstania współczesnej kultury tkwi w wyzwaniu, jakie ta rzeczywistość stawia nie tylko przed samowystarczalnym i autoreferencyjnym rozumem ponowoczesnym, ale przede wszystkim przed samymi wierzącymi, przed ich wiarą. Jedyna możliwość radykalnego odwrócenia współczesnego nihilizmu zawiera się w możliwości odwrócenia negatywnego NIE kultury logosu w pozytywne NIE kultury Miłości, którą Zanghí uważa za wielkie objawienie, jakie Duch Święty podarował Chiarze Lubich, odkrywając przed nią tajemnicę opuszczenia Jezusa na krzyżu. To jest trzeci, fundamentalny etap rozwoju myśli ludzkiej, który nazywa: „myśleniem w kategoriach miłości”48. Byłaby to owa „kultura Ducha”49, która nas wprowadza w Trójcę Świętą, łono nieskończonej Miłości,

${ }^{48}$ Por. Zanghí, „Il pensare”, 11-19.

49 Nie chodzi, oczywiście, o nic podobnego do teologii historii Gioachina di Fiorego z jej charakterystycznym rysem duchowym i wykluczającym. Kiedy Zanghí mówi o Duchu, odnosi się do owego Ducha Syna, który woła: „Ojcze” (por. Ga 4,6). Jesteśmy wciąż w ramach perspektywy postępującego docierania do prawdy o tajemnicy Boga, która nawet jeśli została podarowana od początku cała, wymaga powolnej asymilacji ze strony człowieka. I jest to dar samego Boga, ponieważ on sam prowadzi ten proces. Benedykt XVI wyraził to dobrze podczas Audiencji Generalnej, 10 marca 2010 r., cytując św. Bonawenturę: „Opera Christi non deficiunt, sed proficiunt” („Dzieła Chrystusa nie cofają się, nie pomniejszają, ale postępują”). 
która zawiera i odbija prawdziwe oblicze Boga i prawdziwe oblicze człowieka. Tylko zamieszkując to miejsce, możemy uchwycić dynamikę relacji trynitarnych ad intra, aby rozpoznać je potem ad extra w stworzeniu i w historii ludzkości, która wraz z wcieleniem Słowa została poddana prawdziwej i właściwej zmianie.

W interesującym fragmencie, znajdującym się w jego pośmiertnej, zawierającej niepublikowane teksty książce na temat teologalnego problemu człowieka, hiszpański filozof Xavier Zubiri - mówiąc o relacji między chrześcijaństwem a współczesnym człowiekiem - kontestuje tradycyjną wizję, według której chrześcijaństwo miałoby być w pierwszej kolejności i formalnie religią zbawienia, ponieważ wówczas prawie wyłącznie kładlibyśmy akcent na konstytutywną sytuację nędzy człowieka. Natomiast jego zdaniem chrześcijaństwo jest przede wszystkim i formalnie $(\mathrm{Rz} 2,20)$ pewną morphosis, „Bożą formą całego człowieka [...] przebóstwieniem”" ${ }^{50}$. To oznacza, że jeśli chrześcijaństwo dociera do człowieka w jego kondycji nędzy to po to, żeby otworzyć i ukierunkować tę ograniczoność ku prawdziwemu powołaniu do przebóstwienia. Sądzę, że w naszych czasach, w których - jak mówił Bauman - nikt nie przychodzi na świat z określoną tożsamością i w których samookreślenie się jest odczuwane jako wartość podstawowa, to stwierdzenie baskijskiego myśliciela trzeba wziąć na serio z powodu jego dalekowzroczności, a przede wszystkim z powodu wyzwania, jakie stawia teologii. Kończąc swoje refleksje nad współczesnością, pisze: „Punktem spotkania między współczesnym człowiekiem a chrześcijaństwem nie jest nędza życiowa, ale jego pełnia" ${ }^{51}$.

\section{Perspektywa Chiary Lubich}

W przedstawionej perspektywie ukazuje się jasno, że charyzmat jedności jest szczególnym darem Ducha Świętego na tę pełnię czasów w znaczeniu, jakie nadaje mu filozof baskijski, dla którego oznacza to nową samoświadomość człowieka pomimo wszystkich trudności i ograniczeń. Człowiek współczesny wydaje się maksymalnie czerpać ze swoich możliwości, wolny od wszystkich infantylnych zależności, od tego, co zewnętrzne, a jednocześnie nawet jeśli w sposób chaotyczny, często nieświadomy i często sprzeczny -

${ }^{50}$ Xavier Zubiri, El problema teologal del hombre: cristianismo (Madrid: Alianza Editorial - Fundación Xavier Zubiri, 1997), 18.

51 Tamże, 19. 
mimo wszystko poszukuje nowego autentyzmu, w którym nagie Ja porzuciłoby swoją agresywność i obawy w nowej jedności z drugimi, z Uniwersum, z JEDNYM, z Bogiem.

Jak nie uznać, że mogłoby to być odnowione głoszenie Boga Trójjedynego, Boga Miłości - dążące w sposób istotny ku nowym, trynitarnym relacjom - być tym, czego współczesny człowiek oczekuje w poszukiwaniu pełni? W tej optyce charyzmat jedności - od ponad 70 lat - jest narzędziem, które niesie taką wizję ze wszystkimi tego konsekwencjami dla Kościoła i dla ludzkości w jej licznych wymiarach: jako duchowość, jako praktyka życia, jako program społeczny i kulturowy, bo można w nim dostrzec te charakterystyczne dla antropologii trynitarnej cechy, które - w pełni włączone w humus Magisterium Kościoła i współczesną refleksję teologiczną - mogą dać swój specyficzny wkład w rozwiązanie współczesnych problemów.

„Chiara Lubich zanurzona w życie trynitarne czuła konieczność nadania formy trynitarnej każdej rzeczywistości” ${ }^{52}$ - mówi obrazowo Zanghí. To tutaj powstaje specyficzna synteza, która w pełni dowartościowuje wcielenie, ukazując w świetle osobę ludzką w jej czystej istocie, tzn. wychodząc do odwiecznego zamysłu Ojca, od Trójjedynego. Chodzi o perspektywę czysto biblijną i eschatologiczną tego, jak odkrywa ona nasze bycie w bycie Słowa (Verbum) Wcielonego-Zmartwychwstałego, o to, kim już jesteśmy w Nim, i o to, czym będziemy w wieczności, tą osobą w pełni wyjaśnioną w miłości na wzór Osób Bożych w nieskończonej Miłości Trójcy Świętej ${ }^{53}$.

Wydarzenie krzyża z rozdzierającym krzykiem opuszczonego Syna nawet jeśli tajemniczym i stawiającym wyzwanie rozumowi ludzkiemu jest bramą, kluczem do odczytania tego nieskończonego misterium. Kilka fragmentów, które przytaczamy z bogatego tekstu Chiary Lubich, pomoże nam dostrzec zasadniczą nowość charyzmatu jedności:

52 Giuseppe M. Zanghí, Gesù abbandonato maestro di pensiero (Roma: Città Nuova, 2008), 59.

${ }^{53}$ Zanghí stwierdza: „bycie osobą jest darem ofiarowanym człowiekowi, darem, który ma swój moment początkowy w kondycji indywiduum - w rajskiej kondycji Adam-Ewa i «zakrzywionej» potem przez grzech - aby dojść wyłącznie w Chrystusie do apogeum osoby spełnionej, która może nazywać Boga Ojcem. Osoby, w której niebo i ziemia się stykają; odwieczna «idea», którą Bóg ma wobec mnie, i «rzeczywistość» mnie jako stworzenia; w pełni zjednoczone i doskonale rozróżnione. To jest theanthropia, w której uczestniczy ludzkie stworzenie. Jest to otwarcie drogi całego stworzenia ku kondycji odpowiedniej do «spełnienia» człowieka w Chrystusie” [Giuseppe Maria Zanghí, „Quale uomo per il terzo millennio?”, Nuova Umanità 134 (2001): 273]. 
Jezus, szczególnie w paschalnym wydarzeniu męki, której owocem jest odkupienie i wylanie Ducha Świętego, objawia nam Byt Trójcy Świętej jako Miłość. W tym misterium On ukrzyżowany jest widzialnym obrazem, doskonałym wytłumaczeniem świata stworzonego.

Jezus opuszczony jest cudem unicestwienia tego, co jest, aby byt mógł być. Cud zrozumiały tylko dla tego, kto poznał Miłość, i wie, że w Miłości pokrywają się wszystko i nicość. Stąd też On, moc Boża i mądrość Boża (1 Kor 1,24) ukazał się jako okno Boga, otwarte na oścież na świat i okno ludzkości, poprzez które można kontemplować Boga. [...]

Są trzy Osoby Trójcy Świętej, a mimo to są jednym, ponieważ Miłość nie jest i jest w tym samym czasie. Ojciec jest odróżniony od Syna i od Ducha Świętego, mimo że zawiera Syna i Ducha. Tak samo, jeśli chodzi o Ducha Świętego, który zawiera Ojca i Syna, i jeśli chodzi o Syna, który zawiera Ojca i Ducha Świętego. W relacji Osób Bożych zatem każda, ponieważ jest Miłością, całkowicie jest, nie będąc: ponieważ jest cała perychoretycznie w innych, w odwiecznym podarowaniu siebie. [...]

Analogiczną zasadę wpisał Bóg w relację między ludźmi. Doświadczyliśmy tego wtedy, kiedy Bóg podarował nam swoje światło. Ja sama poczułam, że zostałam stworzona jako dar dla tego, kto jest obok mnie, a ten, kto jest obok mnie, jest stworzony jako dar dla mnie, jak Ojciec w Trójcy jest cały dla Syna, Syn jest cały dla Ojca. Dlatego też relacja między nami to Duch Święty, ta sama relacja, jaka jest między Osobami Trójcy Świętej. Powinniśmy starać się naśladować życie Trójcy Świętej, miłując się wzajemnie miłością, jaką Duch Święty rozlał w naszych sercach, jak Ojciec i Syn się miłują ${ }^{54}$.

Z tego hermeneutycznego klucza, który jest zarazem doświadczeniem mistycznym i refleksją intelektualną, wypływa kilka punktów nowego humanizmu i antropologii, które są na miarę wyzwań naszych czasów i które wcześniej zostały wymienione ${ }^{55}$ :

${ }^{54}$ Chiara Lubich, „Spiritualità dell'unità e vita trinitaria. Lezione per la laurea honoris causa in teologia", Nuova Umanità 151 (2004): 14-15. Doktorat honoris causa przyznany przez Uniwersytet w Trnawie, podczas ceremonii, która miała miejsce w Castel Gandolfo 23 czerwca 2003 r.

55 Por. Chiara Lubich, ,Jezus Wychowawca”, w: Chiara Lubich, Charyzmat jedności, red. Michele Vandeleene (Kraków: Fundacja Mariapoli i Wydawnictwo M, 2007), 308-313; Chiara Lubich, „Przemówienie wygłoszone w UNESCO 17 grudnia 1996 r. z okazji wręczenia Nagrody za «Wychowanie dla Pokoju»", w: Chiara Lubich, Charyzmat jedności, red. Michele Vandeleene (Kraków: Fundacja Mariapoli i Wydawnictwo M, 2007), 45-49; Chiara Lubich, Una cultura nuova per una nuova società. Discorsi in occasione del conferimento di lauree h. c., congressi 
1. Wizja bytu: byt jako miłość. Pomija ontyfikację bytu narzuconą przez rozum, który kończy, aby uchwycić go, utożsamiając z nim samym, i nie dochodząc do bytu-nicości Martina Heideggera, który natomiast o nim wątpi, byt jako miłość ukazuje oblicze nieskończonego Daru (niekonieczność miłości, która jest samym Bogiem, jak mówi Benedykt XVI) ${ }^{56}$, który będąc, pozwala być na tyle, na ile jest przyjęty jako taki.

2. Wizja podmiotu: podmiot Jezus. Wielu staje się jednym w Jezusie, mimo że pozostają odróżnieni (,wszyscy bowiem jesteście kimś jednym w Chrystusie Jezusie"; Ga 3,28). Chiara Lubich nazywa ją Duszą, ,która jednoczyła wszystkie" ${ }^{57}$, Zmartwychwstały pomiędzy nami, jako rzeczywistość eschatologiczna, w którą włącza nas miłość wzajemna.

3. Wizja relacyjności: „relacje trynitarne”. Jean-Luc Marion pisał: „Ja otrzymuję moją indywidualność niezastąpioną dzięki postępowi drugiego w jego spojrzeniu; ja otrzymuję siebie samego jako niezastąpionego z jego własnej ekstazy"58. A Xavier Zubiri stwierdza:

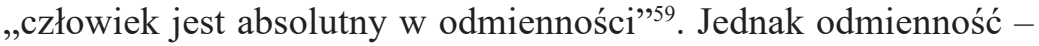
cudownie odkryta i pogłębiona przez personalizm - będzie tylko wtedy płodna, jeśli będzie rozumiana jako relacja konstytutywna i konstytuująca, a zatem jeśli będzie przeżywana jako komunia.

4. Wizja wiedzy: wiedza jako myśl Chrystusa („My właśnie znamy umysł Chrystusa"; 1 Kor 2,16).

5. Wizja duchowości: duchowość komunii, oparta na trzech filarach: Bóg - brat - ja.

6. Projekt kulturowy i społeczny: „Aby wszyscy stanowili jedno”.

Wszystko można streścić w bardzo sugestywnym obrazie Lubich, mogącym z jasnością dynamizmu duchowego i antropologicznego wyrazić tę perspektywę: twierdza zewnętrzna, jest tu ewidentne odniesienie do Teresy z Avila:

e convegni 1996-2001 (Roma: Città Nuova, 2002), 161-173; Chiara Lubich, Inaugurazione del $1^{\circ}$ corso dell'Istituto Superiore di Cultura (Montet, 15/8/2001; Rocca di Papa: Archivio Movimento dei Focolari); Centro Chiara Lubich - Istituto Universitario Sophia, Dottorati honoris causa conferiti a Chiara Lubich (Roma: Città Nuova, 2016), 320-329.

${ }^{56}$ Benedykt XVI, Caritas, nr 34.

57 Chiara Lubich, „Paradiso '49”, Nuova Umanità 177 (2008): 288.

58 Jean Luc Marion, Prolegómenos a la caridad (Madrid: Caparros editores, 1993), 115.

59 Zubiri, Tres dimensiones, 69. 
Nadszedł jednak czas, aby odkrywać, rozświetlać, wznosić nie tylko „zamek wewnętrzny”, ale i ,zamek zewnętrzny” - przynajmniej takie jest nasze powołanie. My widzimy cały Ruch jako „,zamek zewnętrzny”, w którym jest obecny Chrystus - to On rozświetla cały Ruch, od centrum po najdalsze zakątki. Gdy pomyślimy, że ta nowa duchowość, którą Bóg obdarza dzisiaj Kościół, dociera również do osób odpowiedzialnych za Kościół i za społeczeństwo, rozumiemy natychmiast, że ten charyzmat nie czyni tylko z naszego Dzieła ,zamek zewnętrzny", lecz dąży także do zbudowania go w Kościele i w społeczeństwie ${ }^{60}$.

\section{Wskazówki końcowe do adekwatnej praktyki edukacyjnej}

Na zakończenie tylko krótko wspomnę o kilku wskazówkach, które wychodząc od tego, co już zostało powiedziane - mogą być przydatne także na płaszczyźnie pedagogicznej. Przy wielu okazjach Chiara Lubich podkreślała, że na Ruch Fokolari i na jego historię można patrzeć jak na wielkie, nadzwyczajne wydarzenie wychowawcze, w którym są obecne wszystkie elementy wychowania i jest rzeczą oczywistą, że jest w nim także pewna teoria wychowania, ściśle określona pedagogia, która leży u podstaw jego działania wychowawczego.

Podczas wykładu wygłoszonego 10 listopada 2000 r. na Catholic University of America w Waszyngtonie, z okazji wręczenia jej doktoratu honoris causa z pedagogiki - Lubich przedstawia i analizuje ,charakterystyczne elementy naszej pedagogiki, związane z podstawowymi zasadami duchowości, którą żyjemy"

W czytelnym wystąpieniu ukazuje implikacje wychowawcze, jakie wypływają z każdego aspektu duchowości jedności i z antropologii, którą implikuje. Od wielu lat jest to przedmiotem doświadczenia w Ruchu - w każdym kontekście formacyjnym - i poza Ruchem we wszystkich projektach edukacyjnych, które się nim inspirują, w różnych kontekstach kulturowych. Możemy to streścić w następujących punktach:

1. Konieczność autentycznej intencjonalności, która ma prowadzić wychowawcę poprzez całe itinerarium formacyjne, które od tej pory musi być personalne i wspólnotowe jednocześnie.

${ }^{60}$ Chiara Lubich, Duchowość jedności nową droga (Kraków: Fundacja Mariapoli, 2004), $27-28$.

${ }^{61}$ Lubich, Charyzmat, 314. 
2. Odkrycie wymiaru ojcostwa: odkrycie mające wielkie znaczenie, jeśli pomyślimy o zanikaniu postaci Ojca (Absolutu), gdyż pewna kultura starała się podważyć na poziomie teoretycznym i praktycznym postać ojca, to znaczy zasadę autorytetu, często z opłakanym skutkiem, zwłaszcza dla nowych pokoleń.

3. Potrzeba odzyskania autorytetu na płaszczyźnie relacji ludzkich i wychowawczych, konieczna, aby postawić tamę relatywizmowi etycznemu oraz brakowi zasad w życiu indywidualnym, jak również w relacjach międzyosobowych i społecznych, co jest zawsze źródłem wszelkiego rodzaju problemów i przemocy.

4. Dostrzeżenie w każdej osobie jej wyjątkowej, oryginalnej, niepowtarzalnej tożsamości, której należy pomóc dojrzewać, wychowując do odpowiedzialności, do zaangażowania, także poprzez wymagania.

5. Odniesienie do słynnej zasady Jana Amosa Komeńskiego „uczyć wszystkiego wszystkich", jednak zgodnie z pedagogicznymi zasadami stopniowania, które nie wyprzedzają czasu i szanują rozwój każdego.

6. Zdecydowane dążenie do owej egzystencjalnej jedności, by przezwyciężać fragmentaryczność, której człowiek często doświadcza w relacji z sobą samym, z drugim, ze społecznością, z Bogiem.

7. Nieustanne wspieranie w przechodzeniu od początkowej fazy zależności od prawa zewnętrznego do interioryzacji tego prawa, poprzez przezwyciężanie trudności i przeszkód, na które warto spojrzeć jako na konieczne środki wzrostu i dojrzewania.

8. Ciągła czujność, aby nie sprzyjać nadopiekuńczości, która dąży do chronienia szczególnie małoletnich od jakichkolwiek trudności, pozostawiając ich nieprzygotowanymi na nieuchronne próby, błędy, porażki życiowe, i sprawia, że stają się pasywni wobec odpowiedzialności, jaką każdy powinien wziąć za samego siebie, bliźniego, społeczeństwo.

9. Przezwyciężanie ciasnych wzorców życia Ja wpatrzonego w siebie i dążenie do nieustannego przekraczania siebie, do przechodzenia ku drugiemu w odkrywaniu wzajemności, która ubogaca i uwalnia.

10. Ciągle posiadanie świadomości celów, do których zawsze zmierza wychowanie, a którymi są formacja człowieka i jego autonomii, lecz z uwzględnieniem formowania człowieka-relacji, w perspektywie budowania wspólnoty, w której żyje. 
W gruncie rzeczy chodzi o tworzenie wszędzie miejsc i kontekstów, w których dynamika relacji będzie naznaczona miłością, bo jedynie ona pozwala rozkwitać i dojrzewać każdemu zgodnie z cechami, które są mu właściwe i wyjątkowe. Znaczące w tym względzie jest to, co Chiara Lubich napisała w 2004 r.:

Wychowanie jest niezbędne, aby prowadzić osobę ku jej powinności, ku celowi, który jest ważny dla człowieka i dla ludzkości. Co jest potrzebne, aby wychowywać w ten sposób? Jak potrzebna jest wiosna, aby ogród zakwitł, tak potrzebne jest ciepło, które rodzi się z miłości, aby wypuściły pąki prawdy zawarte w człowieku ${ }^{62}$.

Wszystko w perspektywie tej wielkiej utopii, którą jest marzenie o innym świecie, solidarnym, uważnym na zachowanie odmienności, który jednak zdecydowanie dąży ku jedności. W tej wizji nie można się nie odnieść do Maryi i do roli, jaką ona odgrywa w Bożym planie wcielenia Słowa. To ona - jako ikona Trójcy Świętej i najczystszy obraz człowieczeństwa w pełni osobowego (,człowieczeństwa zrealizowanego" - powie Lubich) jak we wszystkich innych epokach, ukazuje ludziom innej nowoczesności ów nowy model antropologiczny, którego gorąco pragną, chociaż czasem nieświadomie.

Ttumaczenie: Wojciech Czekaj

\section{Bibliografia}

Bauman, Zygmunt. Individualmente insieme. Reggio Emilia: Diabasis, 2008. Benedetto XVI. Caritas in Veritate. Poznań: Księgarnia św. Wojciecha, 2006. Carella, Nino. Silvia prima di Chiara. La ricerca di una strada nuova. Roma: Città Nuova, 2014.

Centro Chiara Lubich - Istituto Universitario Sophia. Dottorati honoris causa conferiti a Chiara Lubich. Roma: Città Nuova, 2016.

Chatel, Francesco. „Alla scuola di chi?”. Nuova Umanità 180 (2008): 613-621.

${ }^{62}$ Chiara Lubich, Messaggio al Convegno di SportMeet, Vienna (Austria), settembre 2004 (Rocca di Papa: Archivio Movimento dei Focolari). 
Coda, Piero. „I movimenti ecclesiali, dono dello Spirito”. W: Pontificium Consilium pro Laicis, I movimenti nella Chiesa, 77-103. Città del Vaticano: Libreria Editrice Vaticana, 1999.

Coda, Piero. La Chiesa è il Vangelo. Alle sorgenti della teologia di papa Francesco. Città del Vaticano: Libreria Editrice Vaticana, 2017.

Congregazione per la dottrina della fede. Iuvenescit Ecclesia. Città del Vaticano, 16 maggio 2016.

Falmi, Donato. „Presentazione della collana Studi e Documenti”. W: Qui c'è il dito di Dio. Carlo de Ferrari e Chiara Lubich: il discernimento di un carisma, red. Lucia Abignente, 5-8. Roma: Centro Chiara Lubich - Città Nuova, 2017.

Fariñas Dulce, Maria José. „Neoindividualismo y desigualdad”. El País, 5.01.2005. https://elpais.com/diario/2005/01/05/opinion/1104879608_850215.html [20.09. 2018].

Franciszek. Evangelii gaudium. Città del Vaticano: Libreria Editrice Vaticana, 2013.

Franciszek. Laudato si'. Città del Vaticano: Libreria Editrice Vaticana, 2015.

Franciszek. Lumen Fidei. Città del Vaticano: Libreria Editrice Vaticana, 2013.

Franciszek. Veritatis gaudium. Città del Vaticano: Libreria Editrice Vaticana, 2018.

Giovanni Paolo II. „V Simposio dei Vescovi d'Europa”. L'Osservatore Romano, 7.09.1982.

Giovanni Paolo II. Redemptor hominis. Città del Vaticano: Libreria Editrice Vaticana, 1979.

Hünermann, Peter. Uomini secondo Cristo oggi. L'antropologia di papa Francesco. Città del Vaticano: Libreria Editrice Vaticana, 2017.

Jan Paweł II. Novo Millennio Ineunte. Wrocław: Wydawnictwo TUM, 2000.

Lubich, Chiara. „Il carisma dell'unità e la pedagogia. Estratto della lezione svolta, il 10 novembre 2000, presso la Catholic University of America di Washington, in occasione del conferimento del dottorato honoris causa in pedagogia". W: Chiara Lubich, La Dottrina spirituale, 227-230. Milano: Mondadori, 2001.

Lubich, Chiara. „Paradiso '49”. Nuova Umanità 177 (2008): 285-296.

Lubich, Chiara. „Spiritualità dell'unità e vita trinitaria. Lezione per la laurea honoris causa in teologia". Nuova Umanità 151 (2004): 11-20.

Lubich, Chiara. Charyzmat jedności, red. Michele Vandeleene. Kraków: Fundacja Mariapoli i Wydawnictwo M, 2007.

Lubich, Chiara. Duchowość jedności nową drogą. Kraków: Fundacja Mariapoli, 2004.

Lubich, Chiara. Educazione come vita, red. A. Vincenzo Zani. Brescia: La Scuola, 2010.

Lubich, Chiara. Inaugurazione del $1^{\circ}$ corso dell'Istituto Superiore di Cultura. Montet, 15/8/2001. Rocca di Papa: Archivio Movimento dei Focolari. 
Lubich, Chiara. Messaggio al Convegno di SportMeet, Vienna (Austria), settembre 2004. Rocca di Papa: Archivio Movimento dei Focolari.

Lubich, Chiara. Una cultura nuova per una nuova società. Discorsi in occasione del conferimento di lauree h. c., congressi e convegni 1996-2001. Roma: Città Nuova, 2002.

Lubich, Chiara. Una famiglia per rinnovare la società. Roma: Città Nuova, 1993.

Marion, Jean-Luc. Prolegómenos a la caridad. Madrid: Caparros editores, 1993.

Nussbaum, Martha C. Nie dla zysku. Dlaczego demokracja potrzebuje humanistów. Warszawa: Kultura liberalna, 2016.

Paweł VI. „Populorum progressio”. Wiadomości Diecezjalne (Katowice) 36 (1968): 205-225.

Quartana, Pino. „Introduzione. Avere il Maestro tra di noi”. W: Chiara Lubich, Una famiglia per rinnovare la società, 105-108. Roma: Città Nuova, 1993.

Rifkin, Jeremy. La civiltà dell'empatia. Milano: Mondadori, 2010.

Sobór Watykański II. „Konstytucja duszpasterska o Kościele w świecie współczesnym Gaudium et spes". W: Sobór Watykański II. Konstytucje. Dekrety. Deklaracje. Poznań: Pallottinum, 1967.

Steiner, George. Nauki mistrzów. Poznań: Zysk i spółka, 2007.

Urs von Balthasar, Hans. Teologica. Vol. III. Milano: Jaca Book, 1992.

Zanghí, Giuseppe Maria. „Il pensare come amore. Verso un nuovo paradigma culturale". Nuova Umanità 145 (2003): 1-19.

Zanghí, Giuseppe Maria. „Quale uomo per il terzo millennio?”. Nuova Umanità 134 (2001): 247-277.

Zanghí, Giuseppe Maria. Gesù abbandonato maestro di pensiero. Roma: Città Nuova, 2008.

Zanghí, Giuseppe Maria. Leggendo un carisma. Chiara Lubich e la cultura. Roma: Città Nuova, 2015.

Zanghí, Giuseppe Maria. Notte della cultura europea. Roma: Città Nuova, 2007.

Zubiri, Xavier. El problema teologal del hombre: cristianismo. Madrid: Alianza Editorial - Fundación Xavier Zubiri, 1997.

Zubiri, Xavier. Tres dimensiones del ser humano: individual, social, histórica, red. Jordi Corominas. Madrid: Alianza Editorial - Fundación Xavier Zubiri, 2006. 